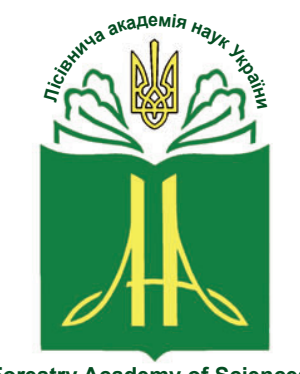

Forestry Academy of Sciences of Ukraine
Наукові праці Лісівничої академії наук України Proceedings of the Forestry Academy of Sciences of Ukraine

http://fasu.nltu.edu.ua https://doi.org/10.15421/412017

Article received 2019.11.14

Article accepted 2020.06.04
ISSN 1991-606X print

ISSN 2616-5015 online

(a) $\square$ Correspondence author

Vitaliy Soloviy

vitsoloviy@yahoo.com

General Chuprynka st., 103, Lviv, 79057, Ukraine

\title{
Urban Governance and Decision-making under Climate Change: a Critical Review of Frameworks, Methods and Tools from the Perspectives of Ecological Economics and Sustainability Science
}

\author{
V. Soloviy' ${ }^{1}$ I. Dubovich ${ }^{2}$
}

\begin{abstract}
Over the past 10-15 years, cities have emerged as clear leaders in global climate action. The wealth of frameworks, methods and tools aimed to support urban climate governance and decision-making have created a picture of progress on the topic, however, practical examples of success are limited to a limited group of forerunners. This research aims to address the gap between needs, theory and practice, by providing a critical review of the current developments from the lenses of sustainability science and ecological economics. Based on their integration, we developed ten minimum criteria for development and selection of actionable means: (1) legitimacy, salience and credibility; (2) consideration of socialecological-economic dynamics; (3) critical pluralism; (4) inclusivity; (5) equality; (6) nexus; (7) transparency; (8) usability; (9) VUCA-fit; 10) transformative potential. The minimum criteria were used to assess 10 selected frameworks, 13 methods and 9 tools, providing decision-makers initial guidelines for making better choices. The analysis revealed that while comprehensive urban climate governance frameworks already exist, sophistication and usability of decisionsupport methods and tools require further work, while common reliance on simple means limits available opportunities. Thus, it is important to make multi-criteria, multi-objective, adaptive and robust approaches better accessible to urban decision-makers beyond the expert circles to support more effective climate action, while the suggested minimum criteria can be used to provide initial guidelines for such developments.
\end{abstract}

Keywords: sustainable cities; just transition; climate economics; adaptation; mitigation; transdisciplinarity; action research; user-centred design; robustness; multi-criteria; no-regret solutions.

Introduction. The unprecedented scale human impacts on the planet over the past few centuries has triggered unseen social and ecological dynamics of high volatility, uncertainty, complexity and ambiguity, which some call the Anthropocene (Steffen et al., 2018). One of its most vivid manifestations is the rapidly escalating climate change, which requires urgent action across multiple levels and scales (Huitema et al., 2016). Over the past two decades and most significantly, since the adoption of the Paris Agreement, cities have become leading actors in ambitious attempts to curb emissions and adapt to climate change. Their role is particularly unique, considering their responsibility for $75 \%$ of global emissions (Couture et al., 2019) and the fact that they are home to over half of the global population (UN DESA, 2019). Large cities are hotspots of climate impacts and vulnerability, which requires particularly responsible and well-calibrated action (Hunt \& Watkiss, 2011). Despite significant progress in urban climate governance over the past decade, it

Vitaliy Soloviy - PhD student, Department for Ecological Economics. Ukrainian National Forestry University, General Chuprynka str., 103, Lviv, 79057, Ukraine. Tel.: +38-097-215-78-78. E-mail: vitsoloviy@yahoo.com ORCID: https://orcid.org/0000-0002-4216-3735

Ion Dubovich - Corresponding Member of the Forestry Academy of Sciences of Ukraine, PhD in Geography, Specialist in International Law, Associate Professor, Head of the Department for Ecological Economics. Ukrainian National Forestry University, General Chuprynka str., 103, Lviv, 79057, Ukraine. Tel.: +38-032-239-27-78. E-mail: iondubovici@ukr.net ORCID: https://orcid.org/0000-0002-3719-7957 
often remains constrained, fragmented and ineffective in regards to the magnitude and scope of the challenges faced by cities, which has led to the context where old, new and emerging frameworks, methods and tools coexist, complement each other, as well as clash and compete (Broto \& Westman, 2020).

Multiple studies have addressed the development of urban climate governance from several different angles (Van Der Heijden, Patterson, Juhola \& Wolfram, 2019), such as meta-reviews and systematic reviews of urban climate governance and plans (Hughes, 2015; Araos et al.,2016; Reckien et al.,2018) or integration of mitigation and adaptation (Grafakos et al., 2020). However, when it comes to the analysis of relevant frameworks, methods and tools the studies are rather scarce and limited in their scope, often focusing on general tools (Bours, McGinn \& Pringle, 2014) or those tailored for a single component of urban climate governance, such as adaptation (Geneletti \& Zardo, 2016), developments not tailored to urban context (Palutikof, Street \& Gardiner, 2019b) or used primarily at the community level (Sharifi, 2016; Nkoana, Verbruggen \& Hugé, 2018). The literature on the specific topic is still in its early stages, focusing on systematizing information and comparing particular tools, identifying gaps and relevant directions of research, however with only emerging critical reflection on broader implications of using particular frameworks, methods and tools (McEvoy, van de Ven, Blind \& Slinger, 2018) or their linkages and connection to broader social contexts or paradigms they operate within.

To address this discrepancy, this study focuses on the analysis of the available frameworks, methods and tools for urban climate governance and decision making from the perspectives of ecological economics and sustainability science. These two fields provide powerful complementary perspectives that allow looking beyond comparison of cost-effectiveness to critically review potential drawbacks and nuances of applying available developments. The key aim of the study is to achieve a better understanding of the paradigmatic and practical implications posed by different frameworks, methods and tools for better urban climate governance and decision-making and to improve the processes of developing and selecting particular frameworks, methods and tools.

Materials and methods. Theoretical lenses. This paper intersects the perspectives of two fields ecological economics and sustainability science, which were chosen considering their mutually enriching agendas and different lenses they provide for analysis of relevant methods and tools.

Sustainability Science represents a heterogeneous set of research programs aiming at the transdisciplinary understanding of the complex social ecological-systems and discovery of transformative and sustainable socioeconomic pathways that integrate multiple drivers, pressures and impacts across different levels and scales (Miller et al., 2014).

Ecological economics is a transdisciplinary research field studying relationships between ecological and economic systems (Spash, 2020).Ecological economists underline the importance of recognizing biophysical reality while aiming to support ecosystem health and human wellbeing as preconditions and goals of economic activity. It is focused on developing economic mindsets, frameworks, methods and tools that are compatible with sustaining life on Earth and supporting genuine human flourishing beyond maximizing profits. Ecological economics provides a highly relevant counter-narrative to the neoclassical economic paradigm which dominates current discussions around climate action. Sustainability science and ecological economics have overlapping agendas, however, their distinct and unique contributions will be emphasized and effectively considered.

Key definitions. Urban climate governance represents a broad discursive approach to urban climate action integration, involving multiple stakeholders, areas of impact and sectors (Gordon, 2018) and integrating cross-level and cross-scale interactions regarding modes of urban mitigation and adaptation to climate change.

Decision-support frameworks, methods and tools provide opportunities to make aware and informed decisions in contexts of high complexity, where individual or group human capacities may prove limited in grasping the scope or magnitude or a particular issue. Approaches that are important for guiding urban governance and decision-making under climate change can roughly grouped into three categories (Tab. 1).

The key difference between tools and methods is that tools have a much lower focus on scientific rigour and more on practical relevance and applicability to real-life.

Data selection. This research was based on critical and integrative review approaches (Snyder, 2019) to assess progress made in the area of decision-support for urban climate change governance. Following the establishment of research aims, scope, theoretical lenses and key concepts, the data selection process was designed, including stages, keywords, keyword groups and criteria. An initial verification search was conducted for all basic combinations to exclude keywords that didn't provide significant results. The further process was as follows:

1) Initial search through Google Scholar and Google Search for groups with a combination of all in the title (each keyword combination divided by coma was searched separately) with Boolean search in title to identify both academic and policy/practice perspectives (Tab. 2). For standard Google Search (group 3), the first 100 search results from each search were selected for further stages. Websites, software, tools, guides and reports by authoritative organizations were included at this stage.

2) Minimum criteria. Exclusion of publications based on minimum criteria of five citations per year on average using Publish or Perish tool for groups 1 and 2 . Only articles published in peer-reviewed journals were included, while books or other types of publications, as well as duplicates, were excluded. 
Key definitions

\begin{tabular}{cl}
\hline \multicolumn{1}{c}{ Concept } & \multicolumn{1}{c}{ Description } \\
\hline Framework & $\begin{array}{l}\text { Frameworks represent a comprehensive and often inter- or transdisciplinary approach outlining a } \\
\text { process or a structure for urban climate governance and/or decision-making, incorporating various } \\
\text { stages and sectors, as well as multiple methods and tools. }\end{array}$ \\
\hline \multirow{3}{*}{ Method } & $\begin{array}{l}\text { Methods provide a way of acquiring knowledge and the analytical instrument used to help find } \\
\text { answers and solutions for urban climate challenges; grounded in a rigorous and accurate scientific } \\
\text { process and theory, resembling a specific type of logic and featuring several well-defined steps. } \\
\text { Methods can be classified by disciplinary focus, degree of integration, stages of the decision- } \\
\text { making process and suitability for particular types of issues. }\end{array}$ \\
& $\begin{array}{l}\text { Tools are practical and hands-on decision-support instruments tailored for policy-makers and } \\
\text { practitioners, with focus on convenience, user-friendly features and effective communication } \\
\text { results. Tools are often implemented in particular software, spreadsheets, web-platform or other } \\
\text { convenient formats. }\end{array}$ \\
\hline
\end{tabular}

Table 2

\section{Search groups. Groups 1 and 2 were used for search in Google Scholar and group 3 was searched in Google search}

\begin{tabular}{|c|c|}
\hline All in the title (AND) & Boolean search in the title (OR) \\
\hline \multicolumn{2}{|c|}{ Group 1. Urban climate governance and decision-making frameworks, methods and tools } \\
\hline $\begin{array}{l}\text { climate city, climate cities, climate urban, climate authorities, } \\
\text { climate municipal, climate municipalities, climate } \\
\text { municipality, climate local, climate community }\end{array}$ & $\begin{array}{c}\text { meta review critical analysis systematic assessment decision } \\
\text { evaluation framework index indicator indicators method } \\
\text { methods tool tools economic concept concepts conceptual } \\
\text { governance }\end{array}$ \\
\hline \multicolumn{2}{|c|}{ Group 2. Ecological economics, sustainability science and climate decision making } \\
\hline $\begin{array}{c}\text { ecological economics, sustainability science, sustainability } \\
\text { climate, sustainable climate }\end{array}$ & $\begin{array}{l}\text { tool tools method methods framework economics economic } \\
\text { decision decisions evaluation assessment indicator indicators } \\
\text { index urban city cities review meta systematic }\end{array}$ \\
\hline \multicolumn{2}{|c|}{ Group 3. From science to practice (web) } \\
\hline $\begin{array}{l}\text { climate city, climate urban, climate municipal climate local, } \\
\text { climate community }\end{array}$ & $\begin{array}{l}\text { framework tool toolkit database knowledge hub guide } \\
\text { guidebook handbook manual platform software }\end{array}$ \\
\hline
\end{tabular}

3) Initial screening. We performed screening of all search results based on fit into at least one of the specific themes relevant for this study: (1) elaboration or use of particular frameworks, models, methods and tools for supporting decisions in urban climate governance; (2) frameworks, methods and tools developed within sustainability science or ecological economics or on the topic decision making under climate change more broadly when relevant for the urban climate governance and decision-making; (3) meta-reviews, systematic, semi-systematic and critical reviews of the current urban climate governance and decision making literature. The criteria were used to classify academic articles and search results within two separate databases into three categories: (a) first priority (b) second priority (c) irrelevant (to be excluded).

4) Full screening. All articles from category (a) were screened in terms of their full texts and further included into the review or removed based on thematic fit. Articles from category (b) were screened for abstracts and then full-text if the abstracts showed their fit to one of the outlined themes. They were further either considered for review based on their relevance or excluded. The same procedure was adopted for web search results, with those from category (a) being screened based on the review of contents and functionality and results from category (b) screened based on the loading page, executive summary or description, and, if relevant, further full screening leading inclusion or exclusion.

5) Extra search. Based on the full screening of all articles and web results from category (a) extra reviews and search were performed. For articles, select articles were included using reverse snowballing, while for web results, tools were amended by search through selected platforms, including Climat-ADAPT, C40 Cities Hub, Climate Toolbox and Climate Adaptation Knowledge Exchange (CAKEX) and weADAPT.

6) Final selection of frameworks, methods and tools was made based on reviewing them for internal consistency, quality of references, originality, usability, relevance and ongoing support. 
This review aimed to provide a critical review on the current landscape of frameworks, methods and tools and thus, we excluded overly similar samples and those without actual value for urban climate governance and decision-making. The summary of the data selection process is provided in the graph below (Fig. 1).

\section{Google Scholar}

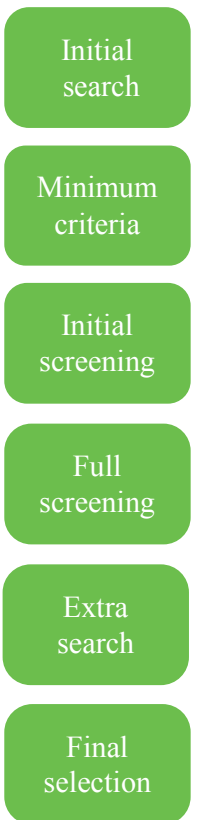

9684 papers identified based on keyword groups 1-3 search in titles

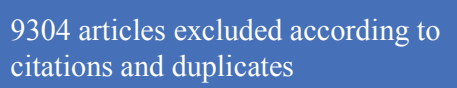

272 articles excluded according to thematic fit based on titles screening

74 articles excluded due to thematic using abstract or full text screening

30 articles added based on forward snowballing

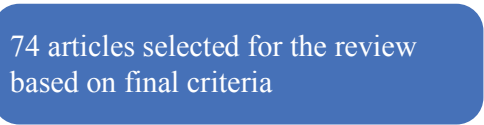

Google Search

6598 search results identified based on keyword group 3 search in titles

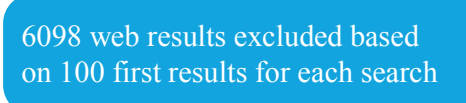

442 web results excluded based on thematic fit and categorization
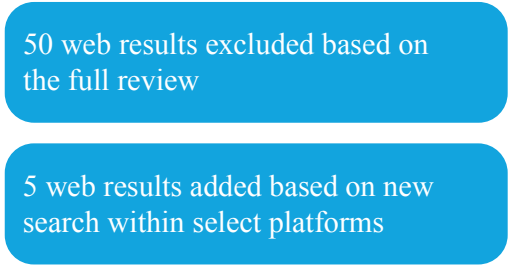

13 web results selected into the review based on final criteria

\section{5 sources selected for review}

Figure 1. Summary of the data selection process

Minimum criteria. Based on integrating perspectives of sustainability science and ecological economics a set of minimum criteria was developed for consideration when selecting relevant methods and tools for supporting urban climate governance and decision making. Based on the current frameworks, reviewed literature, critical perspectives (Hallegatte, Henriet \& Corfee-Morlot, 2011; Whitehead, 2013;
Vogel \& Henstra, 2015; Romsdahl, Blue \& Kirilenko, 2018; Frantzeskaki et al., 2019) and integration of key provisions of sustainability science (Sala, Farioli \& Zamagni, 2013; Fazey et al, 2018) and ecological economics (Spash, 2020; Pirgmaier \& Steinberger, 2019) it was possible to outline ten minimum criteria which decision support frameworks, methods and tools should strive to align with (Tab. 3).

Table 3

Ten minimum criteria for development and selection of urban climate governance and decision making frameworks, methods and tools

\begin{tabular}{lc}
\hline \multicolumn{1}{c}{ Minimum criteria } & Key references \\
\hline 1 & 2 \\
\hline $\begin{array}{l}\text { 1. Validity. Legitimacy, salience and credibility as defined within sustainability } \\
\text { science, being an intersubjective, rather than actor-determined features. }\end{array}$ & $\begin{array}{c}\text { von Wehrden, Luederitz, Leventon } \\
\text { \& Russell, 2017 }\end{array}$ \\
\hline $\begin{array}{l}\text { 2. Holism. Recognition of biophysical, social-ecological and ecological- } \\
\text { economic dynamics, inter/-transdisciplinary approach }\end{array}$ & $\begin{array}{c}\text { Pirgmaier \& Steinberger, 2019; } \\
\text { Mi et al., 2019 }\end{array}$ \\
\hline $\begin{array}{l}\text { 3. Critical pluralism. Consideration of different values and frames e.g. both } \\
\text { monetary and nonmonetary, ethical and cultural awareness }\end{array}$ & $\begin{array}{c}\text { Zografos \& Howarth, 2010; Brink } \\
\text { \& Wamsler, 2018 }\end{array}$ \\
\hline $\begin{array}{l}\text { 4. Inclusivity providing space for participation, deliberation, co-creation and } \\
\text { contestation and difference, particularly in regards to vulnerable groups }\end{array}$ & $\begin{array}{c}\text { Klenk, Fiume, Meehan \& Gibbes, } \\
\text { 2017; Brink \& Wamsler, 2019 }\end{array}$ \\
\hline
\end{tabular}


Continuation of table 3

1

2

5. Equality. Integration of equality, fair distribution, justice and the every-day politics of climate change in cities from the perspective of urban political ecology.

6. Nexus. Consideration of multiple exposures, perspectives, sectors, criteria, objectives and scales, as well as connections, synergies, co-benefits and trade-offs

7. Transparency. Transparency and clarity of the structure, process, roles, parameters, interests, influences and results, as well as debiasing

8. Usability. Balancing of sophistication and smooth user experience, without falling into the 'everything matters' trap while considering different needs

9. VUCA-fit. Capacity to work with no-regret and safe-to-fail options, flexibility, adaptability, learning, innovation and reflexivity.

10. Transformation. Capacity to support thinking outside of the everyday policy and practice, including coverage of such aspects as lock-ins, pathdependencies, politics and transformative change beyond status quo
Hughes, 2015; Anguelovski et al., 2016

Moallemi et al., 2020; Bennett, Blythe, Tyler \& Ban, 2016

Sudmant, Gouldson, MillwardHopkins, Scott, \& Barrett, 2018

Kim et al., 2017; Lawrence, Bell \& Stroombergen, 2019

Ryan, 2015; Webb, Rissik, Petheram, Beh \& Smith, 2019

Hölscher, Frantzeskaki, McPhearson \& Loorbach, 2019

It should be noted that those minimum criteria are not considered to offer silver-bullet solutions, but rather identify low-regret options among available frameworks, methods and tools, which can be used across a wide range of contexts.

Results. Overall, 10 frameworks, 13 methods and 9 tools were selected for the critical review and analysis. They were further assessed in regards to their alignment with minimum criteria identified earlier. Each entry was assessed according to each criterion based on a full review of structure and functional possibilities, case studies. Alignment with minimum criteria was assessed based on formal descriptions, as well as analysis based on search results for at least two relevant key-words and their variations within key references. For each criterion, the entry could gain from 0 to 2 points (Tab. 4) and from 0 to 20 points overall (Tab. 5), leading to the assessment (Tab. 6).

Table 4

\begin{tabular}{cll} 
Alignment scoring for single minimum criteria \\
\hline Color & Points & \multicolumn{1}{c}{ Level of alignment } \\
\hline 0 & $\begin{array}{l}\text { Alignment is not mentioned, } \\
\text { isn't possible or was never featured } \\
\text { in case studies }\end{array}$ \\
\hline 1 & $\begin{array}{l}\text { Alignment possible, however, } \\
\text { requires efforts from the user } \\
\text { to ensure it }\end{array}$ \\
\hline 2 & $\begin{array}{l}\text { Alignment is embedded and makes } \\
\text { up one of the essential features or } \\
\text { stages }\end{array}$ \\
\hline
\end{tabular}

\section{Alignment scoring for single minimum criteria}

Table 5

\section{An overall minimum criteria alignment score}

\begin{tabular}{cl}
\hline Spectre Points & \multicolumn{1}{c}{ Level of alignment } \\
$0-6$ & $\begin{array}{l}\text { Low level of alignment suggests that it is not recommended to use particularly entry or use only as } \\
\text { complementary means for specific occasions, themes or stages without sole reliance on its results } \\
\text { or guidance for making final decisions. Combining few means with low score requires either expert } \\
\text { decision or thorough reflection on their complementarity. }\end{array}$ \\
7-13 & $\begin{array}{l}\text { Medium level of alignment suggests that even though the entry can serve as a helpful element of } \\
\text { the governance and decision-making platform, it is best to combine it with other elements to ensure } \\
\text { robust results. It may also mean dependence on the user's capacity to effectively utilize its features } \\
\text { and thus may not serve as a universal solution for every case. }\end{array}$ \\
\hline 14-20 & $\begin{array}{l}\text { High level of alignment suggests that the entry can be effectively used as core element of the } \\
\text { governance and decision-making platform, with other aspects added depending on its weaker } \\
\text { points as well as context-specific-needs. The use of means even with the highest score will however } \\
\text { depend on the quality of facilitation, data collection and the capacity to apply gained insights in } \\
\text { decision-making. }\end{array}$ \\
\hline
\end{tabular}


Frameworks, methods and tools that had a broad thematic scope, provided integrative perspective and were capable of guiding the full governance or decision-making process were prioritized. Examples aimed at climate aimed primarily at monitoring, data collection, risk or vulnerability assessment, monitoring and reporting were excluded from the review. This allowed us to narrow down the analysis and focus on the most relevant examples. Meanwhile, some nonintegrated examples were included if they provided a comprehensive and highly insightful perspective, structure or process.

Table 6

\section{Assessment of selected frameworks, methods and tools on alignment with minimum criteria ( $\mathrm{S}$ - the sum of points per each criterion)}

\begin{tabular}{|c|c|c|c|c|c|c|c|c|c|c|c|c|c|}
\hline \multirow{2}{*}{$\mathrm{S}$} & \multirow{2}{*}{ Decision-support means } & \multirow{2}{*}{ Acronym } & \multicolumn{10}{|c|}{ Minimum criteria (numbers) } & \multirow{2}{*}{ Key reference } \\
\hline & & & 1 & 2 & 3 & 4 & 5 & 6 & 7 & 8 & 9 & 10 & \\
\hline \multicolumn{14}{|c|}{ FRAMEWORKS } \\
\hline 13 & RESIN Decision Framework & RESIN & & & & & & & & & & & Chapman \& Nieuwenhuijs, 2018 \\
\hline 13 & Urban Planning Support System & UPSS & & & & & & & & & & & Salas \& Yepes, 2019 \\
\hline 14 & Building a Climate-Resilient City & BCRC & & & & & & & & & & & IISD, 2017 \\
\hline 15 & Values-Based Strategic Framework & VBS & & & & & & & & & & & Ingram \& Hamilton, 2014 \\
\hline 15 & Urban Climate Resilience & UCR & & & & & & & & & & & Tyler \& Moench, 2012 \\
\hline 16 & Climate Action Planning & CAP & & & & & & & & & & & $\mathrm{C} 40,2020$ \\
\hline 17 & Social-Ecological Systems & SES & & & & & & & & & & & Flynn \& Davidson, 2016 \\
\hline 17 & Urban Climate Action Impacts & UCAI & & & & & & & & & & & RAMBOLL, 2019 \\
\hline 18 & $\begin{array}{l}\text { Planning and Evaluation of Nature-Based } \\
\text { Solutions }\end{array}$ & NBS & & & & & & & & & & & Raymond et al., 2017 \\
\hline 20 & $\begin{array}{l}\text { Decision-Support Structure and } \\
\text { Evaluation }\end{array}$ & DSSE & & & & & & & & & & & Moallemi et al., 2020 \\
\hline \multicolumn{14}{|c|}{ METHODS } \\
\hline 7 & Cost-Benefit Analysis & $\mathrm{CBA}$ & & & & & & & & & & & Estrada et al. 2017 \\
\hline 7 & Cost-Effectiveness Analysis & CEA & & & & & & & & & & & Raucher et al., 2013 \\
\hline 7 & Real Options Analysis & ROA & & & & & & & & & & & Kwakkel, 2020 \\
\hline 9 & Portfolio Analysis & PA & & & & & & & & & & & $\begin{array}{r}\text { Aerts, Botzen, van der Veen, } \\
\text { Krywkow \& Werners, } 2008\end{array}$ \\
\hline 9 & Multi-Criteria Decision Analysis & MCDA & & & & & & & & & & & Cohen et al., 2019 \\
\hline 9 & Integrated Assessment Modeling & IAM & & & & & & & & & & & Balint et al., 2017 \\
\hline 10 & $\begin{array}{l}\text { Multi-Scalqe Relational Risks \& } \\
\text { Opportunities }\end{array}$ & MS-ReRO & & & & & & & & & & & Salas \& Yepes, 2019 \\
\hline 10 & Agent-Based Modeling & $\mathrm{ABM}$ & & & & & & & & & & & Lamperti et al., 2019 \\
\hline 11 & System Dynamics Modeling & SDM & & & & & & & & & & & Balint et al., 2017 \\
\hline 12 & Dynamic Risks and Opp. Sim. Evaluation & D-ROSE & & & & & & & & & & & Salas \& Yepes, 2019 \\
\hline 12 & Dynamic Adaptive Policy Pathways & DAPP & & & & & & & & & & & Lawrence \& Haasnoot, 2017 \\
\hline 14 & Many-Objective Robust Decision Making & MORDM & & & & & & & & & & & Dittrich, Wreford \& Moran, 2016 \\
\hline 14 & Urban Climate Experimentation & UCE & & & & & & & & & & & Smeds \& Acuto, 2019 \\
\hline \multicolumn{14}{|c|}{\begin{tabular}{|l|l} 
TOOLS AND PLATFORMS \\
\end{tabular}} \\
\hline 7 & CURB & - & & & & & & & & & & & World Bank, 2017 \\
\hline 9 & UKCIP Adaptation Wizard & AW & & & & & & & & & & & $\begin{array}{r}\text { Street, Pringle, Lourenço \& } \\
\text { Nicolletti, } 2019\end{array}$ \\
\hline 10 & Urban Resilience Roadmap & URR & & & & & & & & & & & weADAPT, 2017 \\
\hline 11 & Urban Adaptation Support Tool & UAST & & & & & & & & & & & Climate-ADAPT, 2020 \\
\hline 11 & Climate Change Adaptation Workshops & CCAW & & & & & & & & & & & Church \& Sherikar, 2019 \\
\hline 12 & Climate Action Co-benefits & $\mathrm{CACB}$ & & & & & & & & & & & $\begin{array}{r}\text { Jones, Jenkinsons \& Brammer, } \\
2019\end{array}$ \\
\hline 14 & OpenMORDM & - & & & & & & & & & & & $\begin{array}{r}\text { Hadka, Herman, Reed \& Keller, } \\
2015\end{array}$ \\
\hline 14 & Exploratory Modeling Workbench & EMW & & & & & & & & & & & Kwakkel, 2017 \\
\hline 15 & $\begin{array}{l}\text { Coastal Climate Adaptation Decision } \\
\text { Support }\end{array}$ & CCADC & & & & & & & & & & & Palutikof et al., 2019 \\
\hline
\end{tabular}


Community-level examples have been mostly excluded from the review due to a focus on governance and decision-making at the city scale. Learning tools not tailored for the policy or practical applications were also not included. If a particular framework was paired with a particular tool developed together with it, only the framework was mentioned in the table, with the tool considered as its element. Some of the examples not included in the table above are however mentioned in the discussion. The final list comprises entries that are either commonly used, best practices or provide new, promising perspectives.

Critical review and analysis. Frameworks. The analysis of frameworks revealed a medium-to-high level of alignment with the outlined minimum criteria. While particular frameworks still fall behind on usability, inclusivity or integration of social-ecological and ecological-economic dynamics, half of the selected examples would comply with all minimum criteria under proper use. Despite high levels of alignment, many frameworks are both limited and strong in their unique focus and scope. The majority focus only on certain facets of urban climate governance, with the particular proliferation of adaptation and resilience frameworks.

Frameworks created with participation of $\mathrm{C} 40$ (RAMBOLL，2018; C40，2020) provide effective guidance on inclusivity, integration and transformation, being among the most user-friendly and comprehensive means available. Under the rise of practice-focused frameworks, work done by the academic community remains important, where the evaluation and planning framework for nature-based solutions (Raymond et al., 2017) supports climate choices that are aligned with ecological processes, while social-ecological systems analytical framework (Ostrom, 2009) allows considering system boundaries, spatial and temporal distribution and social dynamics among users. It also allows systematizing complex data, including urban resource flows, relations, productivity, infrastructure and capacities. The Decision-support structure and evaluation by Moallemi et al. (2020) is different from most of the other examples featured since it is a metaframework, dedicated to the design of the governance and decision-making process per see, and allowing to accurately outline multiple facets and stages of urban climate governance and decision-making.

A particular challenge in regards to the effective development of frameworks is the absence of databases dedicated to scientific collaboration on this topic, with only individual reviews, as compared to large databases of tools. Very limited reflection and comparison of the available frameworks have been conducted to date and very often older frameworks are replaced by new ones without case studies to reflect on their effectiveness, And while such a rapid development might be what we need at this point, it also requires new ways of analyzing the complex landscape (Lamb, Creutzig, Callaghan \& Minx, 2019).

Methods. Common types of methods identified include conceptual framing, modelling, analysis, evaluation, assessment, ranking, participation, verification, visualization and experimentation, while integrative rather than partial methods have been chosen for the review.

One of the simplest and common economic evaluation methods, CBA is used for calculating the effectiveness of policies and projects under a single monetary criterion. Standard CBA provides a set of clear benefits, such as simple structure, speedy analysis and clear conclusions (Estrada, Botzen \& Tol, 2017). However, it is prone to many drawbacks, the most common of which include strong dependence on accurate data, commodification and monetization of all climate impacts, common ignorance towards distribution and highly questionable discount rates, which create challenges of possible maladaptation or delayed mitigation.

A more comprehensive standard method is costeffectiveness analysis, which allows calculating alternative ways to use available resources, provides relative ranks per unit of a particular outcome or the least-cost path for a particular goal, as well as costeffectiveness tipping points (Raucher et al., 2013). It can be used for short-term planning of particularly targeted interventions under constrained resources. Some of the benefits include the possibility for effective combination with sensitivity analysis and probabilistic modelling, focus on non-economic outcomes, and relative simplicity. Meanwhile, it requires low levels of risks, low complexity and significant predictability of the outcomes and thus its utility in VUCA-contexts is questionable, creating the possibility of narrow framings that do not consider important positive and negative outcomes. No recognition of complex dynamics or biophysical limits, complex choice in regards to the relevant metrics and no simple way to integrate cobenefits constrain its effectiveness. Overall, those two simple methods are some of the most commonly used guidance for urban climate decision-making, despite being quite limited in their capabilities.

Some of the more complex methods include Real Options Analysis (ROA) and Portfolio Analysis (PA). ROA allows arranging options considering their flexibility to future changes and viability across different time horizons. It also allows comparing consequences, benefits and tradeoffs, and it may be particularly relevant for a long term and complex choices, such as the development of urban adaptation infrastructure or pacing the transition to renewable energy. Clear structure, flexibility, applicability to high-risk context, quantitative and qualitative analysis possibilities are among its strongest sides, however, a complex methodology, high resource and information demands, as well as monetization or ignorance towards non-market values limit its applications and effectiveness. It has also been criticized for a common lack of baselines and overreliance on the probability of different scenarios, which is problematic (Kwakkel, 2020). Meanwhile, PA allows combining different viable options bundles that satisfy the risk-return 
preferences and avoiding underperforming portfolios. Effective visualization, applicability to both monetary and non-monetary goals are some of its key features, however high demand towards expert knowledge, dependence on data and lower effectiveness under deep uncertainty make it less applicable to the context of climate change in cities, which requires more flexible methods.

Multi-criteria decision analysis (MCDA) is one of the most systematic, transparent and inclusive methods available to date. It is used as the foundation for a wide range of urban climate governance decision-support frameworks and tools (Balouktsi, 2019). MCDA allows arranging options and making decisions based on value- or decision-trees, which incorporate weighted criteria and indicators of various types, and can include diverse stakeholder perspectives. Its variations include analytical hierarchy process (AHP), multi-attribute utility theory (MAUT), elimination and choice expressing the reality (ELECTRE), preference ranking organization method for enrichment of evaluations (PROMETHEE) and dominance based rough set approach (DRSA), among others (Cinelli, Coles \& Kirwan, 2014). MCDA is also used within multiple software packages, such as DECERNS, Expert Choice, Make It Rational and Super decisions.

During the past few years, MCDA has become one of the key methods suggested for climate decisionmaking, being capable of balancing different co-benefits and trade-offs (Cohen et al., 2019) as well integrating with other approaches (Munaretto, Siciliano \& Turvan, 2014). However, subjectivity and high demand for organizational capacity can make it hard to implement in real life (Ellen, Yager, Hanson \& Bosher, 2016). Moreover, transparency and inclusivity may happen on paper but not be reflected in the results, while for those who are embedded into the context it is often hard to identify and address discriminatory treatment of viewpoints (Bradley \& Steele, 2015).

Another similar in many respects method is Multiobjective robust decision-making (MORDM), which reveals options that are robust under a wide range of possible futures and multiple goals (Lawrence et al., 2019). Instead of maximizing utility, it focuses on noregret and good-enough options, being particularly effective under deep uncertainty and applicable upon multiple temporal scales. MORDM is also specifically suited to deal with deep uncertainty and avoid maladaptation. However, complexity, significant demand for expert knowledge and quality data, as well as subjectivity are its common drawbacks. Among other methods created to work within the contexts of complexity and uncertainty are Dynamic Adaptive Policy Pathways (DAPP), Multi-Scale Relational Risks \& Opportunities (MS-ReRO) and Dynamic Risks and Opportunities Simulation Evaluation (D-ROSE). D-ROSE is particularly effective in scenario-planning and grasping trade-offs, MS-ReRO is tailored for multiscale assessments (Salas \& Yepes, 2019) and DAPP is suited to the elaboration of future policies, defining prospective measures and tipping points leading to policy shifts. Despite their benefits, complex structure and high requirements towards expert support make them unlikely options for decisionmakers without extra training.

Many of the methods outlined above are usually coupled with models of different complexity and size. Simple integrated assessment models (IAMs) such as Dynamic Integrated model of the Climate and Economy (DICE), are widely used and mostly aim to optimize the system in terms of specific indicators (Balint et al., 2017). However, they have often been criticized for oversimplifying social-ecological and ecologicaleconomic interactions, adopting questionable discount rates and ignoring non-monetary aspects of wellbeing (Spash, 2013). Complex systems models that feature nonlinear system dynamics and agent-based models allowing for heterogeneous perspectives have been considered more promising in addressing modeling challenges (Lamperti et al., 2019). While some of the methods allow for participation, most of the complex methods are used by a limited number of experts in select contexts. One of the ways this challenge is being overcome is through the creation of tailored decisionsupport tools.

Tools and platforms. Tools represent a policy or practical perspective on decision-making within the context of urban climate governance. They are often based on well-recognized frameworks, methods and models, however, may modify their functional attributes or add extra analytical, decision-support or communicative elements. The most common types of tools identified during this review include platforms, dedicated software, analytical tools, strictly decisionsupport tools and guidelines or manuals. A large share of the tools identified relied on CBA-based approaches and monetary valuation, however, a clear shift towards more complex and considerate tools has been witnessed in the post-Paris years.

The CURB tool allows assessing multiple low-carbon options across five steps: setup, inventory, context, action and results. It also allows for conducting cost and impact assessments across six sectors. OpenMORDM and Exploratory Modeling Workbench (EMW) are two similar tools for MORDM that with the first one focusing on analysis (Hadka et al., 2015) and the second one on experimentation through programming via exploratory modelling (Kwakkel, 2017).

While many of the complex offer extended capabilities in return for expert knowledge, accessible platforms are starting to make their way through, covering aspects like climate justice, consumptionbased emissions and transformative perspectives. Some of the decision-making tools, such Urban Adaptations Support Tool (UAST) are actually systematic frameworks with a collection of guidelines for action, different approaches and assessment methods, providing a clear process with a large database of references but little guidance on the selection of viable tools among the wide range of 
options (Climate-ADAPT, 2020). Most of the other identified tools, such as UKCIP Adaptation Wizard (Street et al., 2019), Urban Resilience Roadmap (weADAPT, 2017) and Coastal Climate Adaptation Decision Support (Palutikof et al., 2019) focused on providing users with a similar intuitive and simple web interface with a clear process and references to relevant resources.

Discussion. Based on the analysis of the results, it was possible to identify three general axes over which the frameworks, methods and tools aimed to support urban climate governance and decision-making have developed. The first signifies the transition from data monitoring and accumulation to action-focus (Palutikof et al., 2019a). With the increasing accessibility of data, its mere presence is becoming less significant compared to the extraction of relevant insights. The second significant shift is the move from simplicity and multidisciplinarity towards complexity and inter/ transdisciplinarity. It is particularly vivid in the more recent frameworks, methods and tools, featuring not simply a combination of metrics from different disciplines but opportunities to reveal and analyse important relations and interdependencies (Moallemi et al., 2020). The third important shift is movement from top-down centralized approaches to participation, and inclusivity significantly featured in some of the most recent frameworks, such as C40's Climate Action Planning Framework. Such developments provide new possibilities to engage stakeholders, mitigate risks and make more informed and aware decisions.

A significant challenge, however, is that many of the shifts happened much more vividly in the theoretical realm, while practical transitions are often still underway (Piggott-McKellar, McNamara, Nunn \& Watson, 2019). The prevalence of scientific over practical focus is highly obvious, despite the fact of essentially practical necessity for climate action (Palutikof, Street \& Gardiner, 2019a). Hewitson et al. (2017) suggest that available resources are often far more complex for users than perceived by their developers, while the review by Newman et al. (2017) suggests a significant gap between the development of decision-support systems and their actual use. It is particularly important to consider the nonhomogeneous nature of users, which is challenging to address with tools developed from a global perspective, leading to the case that some tools may not always be considered legitimate or relevant by local users (Palutikof et al. 2019a). There are also emerging examples of effective application of complex and hybrid methods (such as the combination of ROA, MCDA and DAPP), which however requires highly supportive conditions, leadership and effective monitoring (Lawrence et al., 2019).

Despite significant theoretical progress and networking, only a small share of leading cities bear the benefits of most up to date developments, while those with limited access to expertise are left to catch up in the increasingly complex landscape (Lamb et al., 2019). Rapid development, commercialization and tendency towards «black-box» configuration may undermine the availability of novel tools to those who have limited capacities and are often most vulnerable towards climate change (Palutikof et al., 2019a). Developers are not interested in disclosing their methodologies with full detail, which can undermine progress, transparency and integration. Meanwhile, urban climate governance and decision making are often to a large extent determined by people who have limited knowledge about the peculiarities of effective climate mitigation or adaptation (Palutikof et al., 2019a).

One of the most significant insights from the recent literature is that the choice of particular frameworks, methods and tools may lead to significantly different outcomes (McEvoy et al., 2018), while the act of choosing certain method or tool itself may be highly arbitrary, even with all the filtering criteria on a particular platform are well-aligned. In this competitive space, where usability, comfort, access to networks and effective marketing may be far stronger factors than its analytical capacity or inclusivity, many cities may end up using simple tools leading to maladaptation, loss and damages. From an ecological economics perspective, the dominance of CBA-based tools is one of the key challenges since it leads to achieving fragmented perspectives which may limit our understanding of challenges and provide a limited view on solution pathways. The danger to settle for means that work best under current political and institutional systems by «commodifying, quantifying and pricing nature» (Spash, 2013) or «fixing» the climate through negative emissions (Carton, 2019) are particularly significant. This, however, remains a common practice in many global reports and highly-cited analyses on economic dimensions of urban action on climate change (Estrada et al., 2017).

A set of minimum criteria applied to both the development and selection of particular frameworks, methods and tools guiding urban climate governance and decision-making is suggested to address those challenges. Application of such a set of simple minimum criteria can secure against most crucial mistakes and help develop awareness of the aspects not covered by particular means and point to complementary perspectives. In the light of growing rigour of present methods, tools and frameworks, practical solutions can be developed through design thinking, participatory prototyping and engaged user-testing considering the set of suggested criteria. Outside of those minimum criteria, as important is also to develop and use metaframeworks, such as the one suggested by Moallemi et al., 2020 to arrive at particular combinations of methods and tools that work best under given factors, relevant time horizons or the range of available parameters.

Conclusion. Urban climate governance and decision-making frameworks, methods and tools are implicated into their political, academic and cultural contexts, with significant impacts on both theoretical development and practical applications. 
While a wealth of available means to frame and steer urban climate trajectories exist, the use of advanced applications remains limited to specific cases, where a clear leadership on climate action is present, while a general lack of integration is vivid. Considering the urgency and significance of climate challenges, making decisions by solemn economic and at the interest of narrow stakeholder groups interested in supporting the status quo can no longer remain an option for urban governance and decision-making under climate change.

Wider accessibility of well-balanced yet more complex frameworks, methods and tools is needed to allow decision-makers to develop necessary and timely responses. Some of the emerging frameworks, methods and tools are starting to address the need for this complexity, covering such important issues as justice, reflection, displacement and capacity for transformative change, among others. To support those positive trends, minimum criteria was elaborated within this paper and is suggested as a prospective way to both develop actionable means and make good choices in regards to the available ones.

Research limitations. As the focus of this review was to integrate perspectives and critically reflect on the developments and not to systematize or provide a historical viewpoint, mostly qualitative review and analysis were performed. Readers are welcome to use the outlined methodology, keywords and selection process to perform other types of analysis, which can help reveal other relevant trends, as well as broaden the scope of covered frameworks, methods and tools.

\section{References}

Aerts, J. C., Botzen, W., van der Veen, A., Krywkow, J., \& Werners, S. (2008). Dealing with uncertainty in flood management through diversification. Ecology and Society, 13(1). Retrieved from: http://www. ecologyandsociety.org/vol13/iss1/art41/

Anguelovski, I., Shi, L., Chu, E., Gallagher, D., Goh, K., Lamb, Z., ... \& Teicher, H. (2016). Equity impacts of urban land use planning for climate adaptation: Critical perspectives from the global north and south. Journal of Planning Education and Research, 36(3), 333-348. https://doi. org/10.1177/0739456X16645166

Araos, M., Berrang-Ford, L., Ford, J.D., Austin, S.E., Biesbroek, R., \& Lesnikowski, A. (2016). Climate change adaptation planning in large cities: a systematic global assessment. Environmental Science \& Policy, 66, 375-382. https://doi.org/10.1016/j. envsci.2016.06.009

Balint, T., Lamperti, F., Mandel, A., Napoletano, M., Roventini, A., \& Sapio, A. (2017). Complexity and the economics of climate change: a survey and a look forward. Ecological Economics, 138, 252-265. https://doi.org/10.1016/j.ecolecon.2017.03.032

Balouktsi, M. (2019, August). Crafting local climate action plans: An action prioritisation framework using multi-criteria decision analysis. In IOP Conference
Series: Earth and Environmental Science (Vol. 323, No. 1, p. 012075). IOP Publishing. doi:10.1088/17551315/323/1/012075

Bennett, N. J., Blythe, J., Tyler, S., \& Ban, N. C. (2016). Communities and change in the Anthropocene: understanding social-ecological vulnerability and planning adaptations to multiple interacting exposures. Regional Environmental Change, 16(4), 907-926. https://doi.org/10.1007/s10113-015-0839-5

Bours, D., McGinn, C., \& Pringle, P. (2014). Monitoring $\&$ evaluation for climate change adaptation and resilience: A synthesis of tools, frameworks and approaches. SEA Change Community of Practice, and UK Climate Impacts Programme. Retrieved from: https://ukcip.ouce.ox.ac.uk/wp-content/PDFs/SEAChange-UKCIP-MandE-review-2nd-edition.pdf

Bradley, R., \& Steele, K. (2015). Making climate decisions. Philosophy Compass, 10(11), 799-810. https://doi.org/10.1111/phc3.12259

Brink, E., \& Wamsler, C. (2018). Collaborative governance for climate change adaptation: mapping citizen-municipality interactions. Environmental Policy and Governance, 28(2), 82-97. https://doi. org/10.1002/eet.1795

Brink, E., \& Wamsler, C. (2019). Citizen engagement in climate adaptation surveyed: The role of values, worldviews, gender and place. Journal of cleaner production, 209, 1342-1353. https://doi. org/10.1016/j.jclepro.2018.10.164

Broto, V., \& Westman, L.K. (2020). Ten years after Copenhagen: Reimagining climate change governance in urban areas. Wiley Interdisciplinary Reviews: Climate Change, e643. https://doi. org/10.1002/wcc.643

Carton, W. (2019). «Fixing» climate change by mortgaging the future: negative emissions, spatiotemporal fixes, and the political economy of delay. Antipode, 51(3), 750-769. https://doi. org/10.1111/anti.12532

Chapman, E., Nieuwenhuijs, A. (2018). User Guide: The Resin Decision Support Tools For Climate Change Adaptation. European project RESIN Climate Resilient Cities and Infrastructures. Retrieved from: https://resin-cities.eu/fileadmin/user upload/Handbooks/RESIN-D4-3-guide-ENGLISHwww.pdf

Church, S., \& Sherikar, P. (2019). Climate Change Adaptation Workshops: A Planning Guide for Local Government Staff v.2., Almeda County, California Office of Sustainability. Retrieved from: http://www.acgov.org/sustain/documents/ AdaptationWorkshopsGuide-AlamedaCounty.pdf

Cinelli, M., Coles, S. R., \& Kirwan, K. (2014). Analysis of the potentials of multi criteria decision analysis methods to conduct sustainability assessment. Ecological indicators, 46, 138-148. https://doi. org/10.1016/j.ecolind.2014.06.011

Climate-ADAPT (2020). Urban adaptation support tool. Retrieved from: https://climate-adapt.eea. europa.eu/knowledge/tools/urban-ast 
Cohen, B., Blanco, H., Dubash, N.K., Dukkipati, S., Khosla, R., Scrieciu, S., ... \& Torres-Gunfaus, M. (2019). Multi-criteria decision analysis in policymaking for climate mitigation and development. Climate and Development, 11(3), 212-222. https:// doi.org/10.1080/17565529.2018.1445612

Couture et al. (2019). Renewables in Cities 2019 Global Status Report. REN21. Retrieved from: https://www. ren21.net/ Accessed on: 04.01.2020

C40 (2020). Climate Action Planning Framework. C40 Cities. Retrieved from: https://cdn.locomotive. works/sites/ 5 ab 410 c 8 a 2 f42204838f 797 e/ pages/5ae2f92374c4837e195d0e00/files/20200324 C40_Climate_Action_Planning_Framework. pdf? $\overline{159100774 \overline{5}}$

Dittrich, R., Wreford, A., \& Moran, D. (2016). A survey of decision-making approaches for climate change adaptation: Are robust methods the way forward?. Ecological Economics, 122, 79-89. https:// doi.org/10.1016/j.ecolecon.2015.12.006

Ellen, I.G., Yager, J., Hanson, M., \& Bosher, L. (2016). Planning for an uncertain future: Can multicriteria analysis support better decision making in climate planning?. Journal of Planning Education and Research, 36(3), 349-362. https://doi. org/10.1177/0739456X16659911

Estrada, F., Botzen, W.W., \& Tol, R.S. (2017). A global economic assessment of city policies to reduce climate change impacts. Nature Climate Change, 7(6), 403-406. https://doi.org/10.1038/nclimate3301

Fazey, I., Schäpke, N., Caniglia, G., Patterson, J., Hultman, J., Van Mierlo, B., ... \& Al Waer, H. (2018). Ten essentials for action-oriented and second order energy transitions, transformations and climate change research. Energy Research \& Social Science, 40, 54-70. https://doi.org/10.1016/j.erss.2017.11.026

Flynn, C.D., \& Davidson, C.I. (2016). Adapting the social-ecological system framework for urban stormwater management: the case of green infrastructure adoption. Ecology and Society, 21(4). http://dx.doi.org/10.5751/ES-08756-210419

Frantzeskaki, N., McPhearson, T., Collier, M.J., Kendal, D., Bulkeley, H., Dumitru, A., ... \& Oke, C. (2019). Nature-based solutions for urban climate change adaptation: linking science, policy, and practice communities for evidence-based decisionmaking. BioScience, 69(6), 455-466. https://doi. org/10.1093/biosci/biz042

Geneletti, D., \& Zardo, L. (2016). Ecosystem-based adaptation in cities: An analysis of European urban climate adaptation plans. Land use policy, 50, 38-47. https://doi.org/10.1016/j.landusepol.2015.09.003

Gordon, D. J. (2018). Global urban climate governance in three and a half parts: Experimentation, coordination, integration (and contestation). Wiley Interdisciplinary Reviews: Climate Change, 9(6), e546. https://doi.org/10.1002/wcc.546

Grafakos, S., Viero, G., Reckien, D., Trigg, K., Viguie, V., Sudmant, A., ... \& Carter, J. (2020). Integration of mitigation and adaptation in urban climate change action plans in Europe: A systematic assessment. Renewable and Sustainable Energy Reviews, 121, 109623. https://doi.org/10.1016/j.rser.2019.109623

Hadka, D., Herman, J., Reed, P., \& Keller, K. (2015). An open source framework for many-objective robust decision making. Environmental Modelling \& Software, 74, 114-129. https://doi.org/10.1016/j. envsoft.2015.07.014

Hallegatte, S., Henriet, F., \& Corfee-Morlot, J. (2011). The economics of climate change impacts and policy benefits at city scale: a conceptual framework. Climatic change, 104(1), 51-87. https://doi. org/10.1007/s10584-010-9976-5

Hewitson, B., Waagsaether, K., Wohland, J., Kloppers, K., \& Kara, T. (2017). Climate information websites: an evolving landscape. Wiley Interdisciplinary Reviews: Climate Change, 8(5), e470.

Hölscher, K., Frantzeskaki, N., McPhearson, T., \& Loorbach, D. (2019). Tales of transforming cities: Transformative climate governance capacities in New York City, US and Rotterdam, Netherlands. Journal of environmental management, 231, 843857. https://doi.org/10.1016/j.jenvman.2018.10.043

Hughes, S. (2015). A meta-analysis of urban climate change adaptation planning in the US. Urban Climate, 14, 17-29. https://doi.org/10.1016/j. uclim.2015.06.003

Huitema, D., Adger, W.N., Berkhout, F., Massey, E., Mazmanian, D., Munaretto, S., ... \& Termeer, C.C. (2016). The governance of adaptation: choices, reasons, and effects. Introduction to the Special Feature. Ecology and Society, 21(3). http://dx.doi. org/10.5751/ES-08797-210337

Hunt, A., \& Watkiss, P. (2011). Climate change impacts and adaptation in cities: a review of the literature. Climatic change, 104(1), 13-49. https:// doi.org/10.1007/s10584-010-9975-6

IISD (2017). Building a Climate-Resilient City. Prairie Climate Centre. From Risk to Resilience. Retrieved from: https://iisd.org/project/building-climate-resilient-city

Ingram, J., Hamilton, C. (2014). Planning for Climate Change. A strategic, values-based approach for urban planners. Toolkit. United Nations Human Settlements Programme (UN-Habitat). Retrieved from: https://www.zaragoza.es/contenidos/medioambiente/onu/1319-eng-res2_Planning_for_Climate Change_Toolkit.pdf

Jones, E., Jenkinsons, C., \& Brammer, S. (2019). A toolkit for city regions and local authorities. Climate action co-benefits Cutting carbon and improving people's lives Ashden. Retrieved from: https://www. ashden.org/downloads/files/CAC-Chapters-allFINAL.pdf

Kim, Y., Eisenberg, D.A., Bondank, E.N., Chester, M.V., Mascaro, G., \& Underwood, B.S. (2017). Fail-safe and safe-to-fail adaptation: decision-making for urban flooding under climate change. Climatic Change, 145(3-4), 397-412. https:// doi.org/10.1007/s10584-017-2090-1 
Klenk, N., Fiume, A., Meehan, K., \& Gibbes, C. (2017). Local knowledge in climate adaptation research: Moving knowledge frameworks from extraction to co-production. Wiley Interdisciplinary Reviews: Climate Change, 8(5), e475. https://doi.org/10.1002/ wcc. 475

Kwakkel, J.H. (2017). The Exploratory Modeling Workbench: An open source toolkit for exploratory modeling, scenario discovery, and (multi-objective) robust decision making. Environmental Modelling \& Software, 96, 239-250. https://doi.org/10.1016/j. envsoft.2017.06.054

Kwakkel, J.H. (2020). Is real options analysis fit for purpose in supporting climate adaptation planning and decision-making?. Wiley Interdisciplinary Reviews: Climate Change, 11(3), e638. https://doi. org/10.1002/wcc.638

Lamb, W. F., Creutzig, F., Callaghan, M. W., \& Minx, J. C. (2019). Learning about urban climate solutions from case studies. Nature Climate Change, 9(4), 279-287. https://doi.org/10.1038/s41558-019-0440-x

Lamperti, F., Mandel, A., Napoletano, M., Sapio, A., Roventini, A., Balint, T., \& Khorenzhenko, I. (2019). Towards agent-based integrated assessment models: examples, challenges, and future developments. Regional environmental change, 19(3), 747-762. https://doi.org/10.1007/s10113-018-1287-9

Lawrence, J., \& Haasnoot, M. (2017). What it took to catalyse uptake of dynamic adaptive pathways planning to address climate change uncertainty. Environmental Science \& Policy, 68, 47-57. https:// doi.org/10.1016/j.envsci.2016.12.003

Lawrence, J., Bell, R., \& Stroombergen, A. (2019). A hybrid process to address uncertainty and changing climate risk in coastal areas using dynamic adaptive pathways planning, multi-criteria decision analysis \& real options analysis: a New Zealand application. Sustainability, 11(2), 406. https://doi.org/10.3390/ su11020406

McEvoy, S., van de Ven, F.H., Blind, M.W., \& Slinger, J. H. (2018). Planning support tools and their effects in participatory urban adaptation workshops. Journal of environmental management, 207, 319333. https://doi.org/10.1016/j.jenvman.2017.10.041

Mi, Z., Zheng, J., Meng, J., Zheng, H., Li, X., Coffman, D.M., ... \& Guan, D. (2019). Carbon emissions of cities from a consumption-based perspective. Applied Energy, 235, 509-518. https:// doi.org/10.1016/j.apenergy.2018.10.137

Miller, T.R., Wiek, A., Sarewitz, D., Robinson, J., Olsson, L., Kriebel, D., \& Loorbach, D. (2014). The future of sustainability science: a solutions-oriented research agenda. Sustainability science, 9(2), 239-246.

Moallemi, E.A., Zare, F., Reed, P.M., Elsawah, S., Ryan, M.J., \& Bryan, B.A. (2020). Structuring and evaluating decision support processes to enhance the robustness of complex human-natural systems. Environmental Modelling \& Software, 123, 104551. https://doi.org/10.1016/j.envsoft.2019.104551
Munaretto, S., Siciliano, G., \& Turvani, M.E. (2014). Integrating adaptive governance and participatory multicriteria methods: a framework for climate adaptation governance. Ecology and Society, 19(2). http://dx.doi.org/10.5751/ES-06381-190274

Newman, J. P., Maier, H. R., Riddell, G. A., Zecchin, A. C., Daniell, J.E., Schaefer, A. M., ... \& Newland, C.P. (2017). Review of literature on decision support systems for natural hazard risk reduction: Current status and future research directions. Environmental Modelling \& Software, 96, 378-409.

Nkoana, E.M., Verbruggen, A., \& Hugé, J. (2018). Climate change adaptation tools at the community level: An Integrated literature review. Sustainability, 10(3), 796. https://doi.org/10.3390/su10030796

Ostrom, E. (2009). A general framework for analyzing sustainability of social-ecological systems. Science, 325(5939), 419-422. doi: 10.1126/science.1172133

Palutikof, J.P., Street, R. B., \& Gardiner, E.P. (2019a). Decision support platforms for climate change adaptation: an overview and introduction. Climatic Change, 153(4). 459-476. https://doi.org/10.1007/ s10584-019-02445-2

Palutikof, J. P., Street, R. B., \& Gardiner, E.P. (2019b). Looking to the future: guidelines for decision support as adaptation practice matures. Climatic Change, 153(4), 643-655. https://doi.org/10.1007/s10584019-02404-X

Palutikof, J.P., Rissik, D., Webb, S., Tonmoy, F. N., Boulter, S.L., Leitch, A.M., ... \& Campbell, M.J. (2019). CoastAdapt: an adaptation decision support framework for Australia's coastal managers. Climatic Change, 153(4), 491-507. https://doi.org/10.1007/ s10584-018-2200-8

Piggott-McKellar, A. E., McNamara, K.E., Nunn, P. D., \& Watson, J.E. (2019). What are the barriers to successful community-based climate change adaptation? A review of grey literature. Local Environment, 24(4), 374-390. https://doi.org/10.108 0/13549839.2019.1580688

Pirgmaier, E., \& Steinberger, J. K. (2019). Roots, Riots, and Radical Change - A Road Less Travelled for Ecological Economics. Sustainability, 11(7), 2001 https://doi.org/10.3390/su11072001

RAMBOLL (2018). Urban Climate Action Impacts Framework. Retrieved from: https://ramboll.com/ media/rgr/ramboll-helps-world-cities-make-thecase-for-climate-actions

Raucher, R., Clements, J., Colley, M., Henderson, J., Potter, J., Rowan, E., \& Sussman, F., Teter, C. (2013). Evaluating Adaptation Options: Assessing Cost, Effectiveness, Co-Benefits, and Other Relevant Considerations. CCRD Whitepaper. USAID. Retrieved from: https:/www.climatelinks.org/ resources/evaluating-adaptation-options-assessingcost-effectiveness-co-benefits-and-other-relevant Accessed on 20.04.2020

Raymond, C.M., Frantzeskaki, N., Kabisch, N., Berry, P., Breil, M., Nita, M.R., ... \& Calfapietra, C. (2017). A framework for assessing and implementing 
the co-benefits of nature-based solutions in urban areas. Environmental Science \& Policy, 77, 15-24. https://doi.org/10.1016/j.envsci.2017.07.008

Reckien, D., Salvia, M., Heidrich, O., Church, J.M., Pietrapertosa, F., De Gregorio-Hurtado, S., ... \& Orru, H. (2018). How are cities planning to respond to climate change? Assessment of local climate plans from 885 cities in the EU-28. Journal of Cleaner Production, 191, 207-219. https://doi.org/10.1016/j. jclepro.2018.03.220

Romsdahl, R., Blue, G., \& Kirilenko, A. (2018). Action on climate change requires deliberative framing at local governance level. Climatic Change, 149(3-4), 277-287. https://doi.org/10.1007/s10584-018-2240-0

Ryan, D. (2015). From commitment to action: a literature review on climate policy implementation at city level. Climatic Change, 131(4), 519-529. https:// doi.org/10.1007/s10584-015-1402-6

Sala, S., Farioli, F., \& Zamagni, A. (2013). Progress in sustainability science: lessons learnt from current methodologies for sustainability assessment: Part 1. The international journal of life Cycle Assessment, 18(9), 1653-1672. https://doi.org/10.1007/s11367012-0508-6

Salas, J., \& Yepes, V. (2019). MS-ReRO and D-ROSE methods: Assessing relational uncertainty and evaluating scenarios' risks and opportunities on multi-scale infrastructure systems. Journal of cleaner production, 216, 607-623. https://doi.org/10.1007/ s11367-012-0508-6

Sharifi, A. (2016). A critical review of selected tools for assessing community resilience. Ecological Indicators, 69, 629-647. https://doi.org/10.1016/j. ecolind.2016.05.023

Snyder, H. (2019). Literature review as a research methodology: An overview and guidelines. Journal of Business Research, 104, 333-339.

Smeds, E., \& Acuto, M. (2018). Networking cities after Paris: Weighing the ambition of urban climate change experimentation. Global Policy, 9(4), 549559. https://doi.org/10.1111/1758-5899.12587

Spash, C.L. (2013). The shallow or the deep ecological economics movement?. Ecological Economics, 93, 351-362. https://doi.org/10.1016/j. ecolecon.2013.05.016

Spash, C. L. (2020). A tale of three paradigms: Realising the revolutionary potential of ecological economics. Ecological Economics, 169, 106518. https://doi. org/10.1016/j.ecolecon.2019.106518

Steffen, W., Rockstrom, J., Richardson, K., Lenton, T., Folke, C., Liverman, D., ... Schellnhuber, H. (2018). Trajectories of the Earth System in the Anthropocene. Proceedings of the National Academy of Sciences of the United States, 115(33), 8252-8259. https://doi. org/10.1073/pnas.1810141115

Street, R.B., Pringle, P., Lourenço, T.C., \& Nicolletti, M. (2019). Transferability of decisionsupport tools. Climatic Change, 153(4), 523-538. https://doi.org/10.1007/s10584-018-2263-6
Sudmant, A., Gouldson, A., Millward-Hopkins, J., Scott, K., \& Barrett, J. (2018). Producer cities and consumer cities: Using production-and consumptionbased carbon accounts to guide climate action in China, the UK, and the US. Journal of Cleaner Production, 176, 654-662. https://doi.org/10.1007/ s10584-018-2263-6

Tyler, S., \& Moench, M. (2012). A framework for urban climate resilience. Climate and development, 4(4), 311-326. https://doi.org/10.1080/17565529.201 2.745389

UN DESA (2019). World Urbanization Prospects: The 2018 Revision (ST/ESA/SER.A/420). United Nations. Department of Economic and Social Affairs, Population Division. New York: United Nations. Retrieved from: https://population.un.org/wup/ Publications/Files/WUP2018-Report.pdf Accessed on: 11.01.2020

Van der Heijden, J., Patterson, J., Juhola, S., \& Wolfram, M. (2019). Advancing the role of cities in climate governance-promise, limits, politics. Special section: 365-373. https://doi.org/10.1080/09640568. 2018.1513832

Vogel, B., \& Henstra, D. (2015). Studying local climate adaptation: A heuristic research framework for comparative policy analysis. Global Environmental Change, 31, 110-120. https://doi.org/10.1016/j. gloenvcha.2015.01.001

von Wehrden, H., Luederitz, C., Leventon, J., \& Russell, S. (2017). Methodological challenges in sustainability science: A call for method plurality, procedural rigor and longitudinal research. Challenges in Sustainability, 5(1), 35-42. https:// doi:10.12924/cis2017.05010035

weADAPT (2017). Urban Resilience Roadmap. USAID. Retrieved from: http://urbanresilienceroadmap. weadapt.org/process-map.html

Webb, R., Rissik, D., Petheram, L., Beh, J.L., \& Smith, M.S. (2019). Co-designing adaptation decision support: meeting common and differentiated needs. Climatic Change, 153(4), 569-585. https://doi. org/10.1007/s10584-018-2165-7

Whitehead, M. (2013). Neoliberal urban environmentalism and the adaptive city: Towards a critical urban theory and climate change. Urban Studies, 50(7), 1348-1367. https://doi. org/10.1177/0042098013480965

World Bank (2017). CURB Tool. Climate Action for Urban Sustainability. Version 2.0 (Open Beta). User Guide. Retrieved from: http://documents.worldbank. org/curated/en/499791474471650053/User-guide

Zografos, C., \& Howarth, R. B. (2010). Deliberative ecological economics for sustainability governance. Sustainability, 2(11), 3399-3417. https://doi. org/10.3390/su2113399 


\section{Управління та прийняття рішень щодо розвитку міст в умовах змін клімату: критичний огляд рамкових умов, методів та інструментів крізь призму екологічної економіки і сталого розвитку}

\section{В.І. Соловій', І.А. Дубовіч²}

Впродовж минулих 10-15 років міста стали безперечними лідерами в діях щодо глобальних змін клімату. Різноманіття рамкових умов, методів та інструментів, спрямованих на підтримку управління та прийняття рішень щодо розвитку міст в умовах змін клімату, створили враження швидкого прогресу, втім реальні приклади успіху обмежені невеликою кількістю передових міст. Стаття спрямована на подолання розбіжності між потребами, теорією та впровадженням наявних засобів крізь призму екологічної економіки і сталого розвитку. Розроблено десять мінімальних критеріїв для вибору дієвих засобів, а саме: 1) легітимність, значущість та надійність; 2) врахування соціо-еколого-економічної динаміки; 3) критичний плюралізм; 4) інклюзивність; 5) рівність; 6) нексус; 7) прозорість; 8) зручність використання; 9) дієвість в умовах VUCAсвіту; 10) потенціал для трансформацій. Відповідно до цих критеріїв було оцінено 10 рамкових умов, 13 методів та 9 інструментів, що може надати особам, які приймають рішення, основу для розуміння базових переваг і недоліків окремих засобів. Половина виявлених рамкових умов, а також деякі методи та інструменти частково відповідають мінімальним критеріям. Втім, найпоширеніші методи та інструменти підтримки прийняття рішень переважно потребують доопрацювання або заміни такими, які краще адаптовані до сучасних умов і потреб, особливо в таких аспектах, як користувацький досвід, трансформаційний потенціал та належне врахування соціо-еколого-економічної динаміки.

Важливо зазначити, що прийняття рішень щодо сталого розвитку міст в умовах змін клімату відбувається у рамках різних політичних, академічних і культурних контекстів, що має істотний вплив як на теоретичну розробку, так і на практичне застосування. Незважаючи на те, що існує безліч доступних засобів, використання досконаліших 3 них залишається прерогативою вузького кола користувачів, в той час як використання традиційних економічних ме-

Соловій Віталій Ігорович - аспірант кафедри екологічної економіки. Національний лісотехнічний університет України, вул. генерала Чупринки, 103, м. Львів, 79057, Україна. Тел.: +38097-215-78-78. E-mail: vitsoloviy@yahoo.com ORCID: https:// orcid.org/0000-0002-4216-3735

Дубовіч Іон Андрійович - член-кореспондент Лісівничої академії наук України, кандидат географічних наук, спеціаліст 3 міжнародного права, доцент, завідувач кафедри екологічної економіки. Національний лісотехнічний університет України, вул. генерала Чупринки, 103, м. Львів, 79057, Україна. Тел.: +38-032-239-27-78. E-mail: iondubovici@ukr.net ORCID: https://orcid.org/0000-0002-3719-7957 тодів у поєднанні зі спрощеними рамковими умовами залишається загальною практикою. Особливо значущою є небезпека розробки і застосування засобів, заснованих на обмежених засадах комодифікації, калькуляції та суто монетарної оцінки, які легко та зручно втілювати в сучасних політичних реаліях. Цей підхід призводить до спрощеного сприйняття клімату, як такого, який можна «відремонтувати» шляхом втілення кількох оптимально підібраних заходів, що втім загрожує непоправною шкодою та втратою можливості досягти цілей Паризької угоди і зберегти життєздатний клімат.

Зважаючи на актуальність викликів, пов'язаних зі змінами клімату, потрібно покращувати доступність добре збалансованих, але більш складних рамкових умов, методів та інструментів, щоб приймати краще поінформовані, зважені і вчасні рішення. Розвиток багатокритеріальних, багатоцільових, адаптивних, стійких i трансформаційних методів та інструментів у напрямі кращої доступності для неекспертної аудиторії сприятиме ефективнішим діям стосовно змін клімату, а запропоновані мінімальні критерії можуть надати для цього базові дороговкази.

Ключові слова: сталі міста; справедливий перехід; економіка змін клімату; пом'якшення; адаптація; трансдисциплінартність; дослідження, спрямовані на зміни; дизайн, орієнтований на користувача; стійкість; багатокритеріальність; безпрограшні рішення.

\section{Управления и принятия решений по развитию городов в условиях изменений климата: критический обзор рамочных условий, методов и инструментов через призму экологической экономики и устойчивого развития}

\section{В.И. Соловий' И. А. Дубович²}

На протяжении прошлых 10-15 лет города стали безупречными лидерами в действиях относительно глобальных изменений климата. Многообразие рамочных условий, методов и инструментов поддержки управления и принятия решений по развитию городов в условиях изменений климата созда-

Соловий Виталий Игоревич - аспирант кафедры экологической экономики. Национальный лесотехнический университет Украины, ул. генерала Чупринки, 103, г. Львов, 79057, Украина. Тел.: +38-097-215-78-78 E-mail: vitsoloviy@yahoo. com ORCID: https://orcid.org/0000-0002-4216-3735

Дубович Ион Андреевич - член-корреспондент Лесной академии наук Украины, кандидат географических наук, специалист с международного права, доцент, заведующий кафедрой экологической экономики. Национальный лесотехнический университет Украины, ул. генерала Чупринки, 103, г. Львов, 79057, Украина. Тел.: +38-032-239-27-78. E-mail: iondubovici@ukr.net ORCID: https://orcid.org/0000-0002-3719-7957 
ли впечатление быстрого прогресса, но реальные примеры успеха ограничены небольшим количеством передовых городов. Это исследование направлено на преодоление расхождения между потребностями, теорией и применимости имеющихся средств сквозь призму экологической экономики и устойчивого развития. Разработаны десять минимальных критериев для выбора действенных средств, а именно: 1) легитимность, значимость и надежность; 2) учет социо-эколого-экономической динамики; 3) критический плюрализм; 4) инклюзивность; 5) равенство; 6) нексус; 7) прозрачность; 8) удобство; 9) действенность в условиях VUCAмира; 10) потенциал для трансформаций. Согласно этим критериям, были оценено 10 рамочных условий, 13 методов и 9 инструментов, что может помочь лицам, принимающим решения, понять базовые преимущества и недостатки отдельных средств.

Половина выявленных рамочных условий, а также некоторые из методов и инструментов по крайней мере частично соответствуют минимальным критериям. Наиболее распространенные на сегодняшний день методы и инструменты поддержки принятия решений требуют доработки или замены такими, которые лучше адаптированы к современным условиям и потребностям, особенно в таких аспектах, как пользовательский опыт, трансформационный потенциал, интеграция социоэколого-экономической динамики и взаимосвязей.

Важно учитывать, что принятие решений по устойчивому развитию городов в условиях изменений климата происходит в рамках различных политических, академических и культурных контекстов, что оказывает существенное влияние как на теоретическую разработку, так и на практическое применение. Несмотря на то, что существует мно- жество доступных средств, использование более совершенных из них остается прерогативой узкого круга пользователей, в то время как использование традиционных экономические методов в сочетании с упрощенным рамочными условиями остается общей практикой. Особенно значима опасность разработки и применения средств, основанных на ограниченных идеях комодификации, калькуляции и чисто монетарной оценки, которые легко и удобно воплощать в современных политических реалиях. Этот подход приводит к упрощенному восприятию климата, как такового, который можно «отремонтировать» путем внедрения нескольких оптимально подобранных мер, что грозит невосполнимым ущербом, потерей возможности достичь целей Парижского соглашения и сохранить жизнеспособный климат.

Учитывая актуальность вызовов, связанных с изменениями климата, нужно улучшать доступность хорошо сбалансированных, но более сложных рамочных условий, методов и инструментов, чтобы принимать лучше информированы, взвешенные и своевременные решения. Развитие многокритериальных, многоцелевых, адаптивных, устойчивых и трансформационных методов и инструментов в направлении лучшей доступности для неэкспертной аудитории будет способствовать эффективным действиям по изменению климата, а предложенные минимальные критерии могут предоставить для этого базовые указатели.

Ключевые слова: устойчивые города; справедливый переход; экономика изменений климата; смягчения; адаптация; трансдисциплинартность; исследования, направлены на изменения; дизайн, ориентированный на пользователя; устойчивость; многокритериальность; беспроигрышные решения. 